\title{
IMAGERY IDENTIFICATION OF TOMATOES WHICH CONTAIN PESTICIDES USING LEARNING VECTOR QUANTIZATION
}

\author{
Ade Sumarsono $^{* 1}$, Supatman ${ }^{2}$ \\ ${ }^{1,2}$ Informatika, Fakultas Teknologi Informasi, Universitas Mercu Buana Yogyakarta, Indonesia \\ Email: ${ }^{1}$ adesumarsono1990@gmail.com, ${ }^{2}$ supatman@mercubuana-yogya.ac.id
}

(Naskah masuk: 26 Juli 2020, diterima untuk diterbitkan: 02 Desember 2020)

\begin{abstract}
Tomatoes have a risk of carrying pesticides above the maximum residue limit (MRL) because the fruit is directly sprayed with pesticides during its production process. Pesticide residue in farmers' produce pose indirect effects to the consumers, but in the long run, it may cause health problems such as neural disorders as well as enzyme metabolism. This research identifies the image of tomatoes containing pesticides by using two types of tomatoes were used as samples, namely tomatoes which contain pesticides, and those which do not contain pesticides. This research aims to develop an algorithm to identify tomatoes that contain pesticides and those which do not contain pesticides using Learning Vector Quantization (LVQ). The characteristics used to identify tomato images are average, variant, and standard deviation. This research consisted of two classes and used 40 training image data and 40 test image data for each class. During the training process using LVQ parameters, there were $98.75 \%$ best percentage at alpha 0.001 and decalpha 0.9 with the lowest iteration of 3 . The final weight obtained from the parameters was then used to perform test data identification. In terms of the best performance on the test data, it was with alpha 0.001 and decalpha 0.9, which reached $97.5 \%$.
\end{abstract}

Keywords: histogram, learning vector quantization (LVQ), tomatoes.

\section{IDENTIFIKASI CITRA TOMAT YANG MENGANDUNG PESTISIDA DENGAN LEARNING VECTOR QUANTIZATION}

\begin{abstract}
Abstrak
Tomat merupakan jenis buah yang berpeluang mengandung residu pestisida melebihi batas maksimum residu (BMR) karena buah disemprot pestisida secara langsung selama proses produksi. Residu pestisida yang terdapat dalam produk pertanian menimbulkan efek yang bersifat tidak langsung terhadap konsumen, namun dalam jangka panjang dapat menyebabkan gangguan kesehatan diantaranya berupa gangguan pada syaraf dan metabolisme enzim. Penelitian ini mengidentifikasi citra tomat yang mengandung pestisida dengan menggunakan dua sampel tomat, yaitu tomat yang mengandung pestisida dan tomat yang tidak mengandung pestisida. Tujuan dalam penelitian ini adalah menghasilkan algoritma untuk mengidentifikasi tomat berpestisida dan tomat tanpa pestisida menggunakan Learning Vector Quantization (LVQ). Ciri yang digunakan untuk mengidentifikasi citra tomat adalah rata-rata, varian, standar deviasi. Penelitian ini terdiri dari 2 kelas dan menggunakan 40 data citra pelatihan dan 40 data citra uji untuk masing-masing kelas. Pada proses pelatihan menggunakan parameter LVQ terdapat persentase terbaik sebesar $98.75 \%$ pada alfa 0.001 dan decalfa 0.9 dengan iterasi terendah 3. Bobot akhir yang diperoleh dari parameter tersebut kemudian digunakan untuk melakukan pengenalan data uji. Unjuk kerja terbaik dari data uji adalah dengan alfa 0.001 dengan decalfa 0.9 dan mencapai $97.5 \%$.
\end{abstract}

Kata kunci : histogram, learning vector quantization (LVQ), tomat.

\section{PENDAHULUAN}

Tomat merupakan sayuran yang banyak dikomsumsi oleh rumah tangga di Indonesia, baik dalam keadaan segar maupun sebagai bumbu. Di sisi lain, perkembangan industri makanan menyebabkan permintaan tomat untuk kebutuhan bahan baku olahan terus meningkat. Dikaitkan dengan masalah keamanan pangan, tomat dapat dikatakan sebagai jenis sayuran yang berpeluang mengandung residu pestisida melebihi batas maksimum residu (BMR) karena disemprot pestisida secara langsung selama proses produksi

Petani non-organik menyemprotkan pestisida sintetis pada tanaman untuk membasmi hama dan 
serangga. Semakin besar pestisida yang di semprotkan, tanaman makin menyerap pestisida beserta residunya dan menempel pada kulit buah atau sayuran. Saat menyantap buah dan sayuran, kandungan pestisida itu turut termakan, bahkan setelah dicuci bersih sekalipun. Pestisida merupakan bahan kimia, sehingga penggunaan yang berlebihan dapat menjadi sumber pencemar pada bahan pangan, air dan lingkungan hidup. Residu pestisida yang terdapat dalam produk pertanian menimbulkan efek yang bersifat tidak langsung terhadap konsumen, namun dalam jangka panjang dapat menyebabkan gangguan kesehatan diantaranya berupa gangguan pada syaraf dan metabolisme enzim.

Dalam membedakan tomat yang mengandung pestisida dan yang tidak mengandung pestisida sangatlah sulit. Maka dari itu, pembuatan sistem identifikasi sangat bermanfaat untuk membantu mengidentifikasi buah yang mengandung pestisida terutama pada tomat menggunakan ekstraksi ciri warna dari data citra dengan metode Learning Vector Quantization. Dengan algoritma ini nantinya dapat mengidentifikasi tomat yang mengandung pestisida dan tomat yang tidak mengandung pestisida sehingga kesalahan dalam pemilihan tomat dapat diminimalisir.

Dalam penelitian ini dirumuskan beberapa masalah yaitu: (1) Bagaimana akuisisi tomat? (2) Bagamana mendesain algoritma pra-prosessing, ekstraksi ciri dan Learning Vector Quantization untuk identifikasi citra tomat yang mengandung pestisida? (3) Bagaimana mengkodekan rancangan algoritma pra-processing, ekstraksi ciri dan Learning Vector Quantization identifikasi tomat yang mengandung pestisida pada bahasa pemrograman? (4) Bagaimana unjuk kerja identifikasi citra tomat dengan Learning Vector Quantization ?

Tujuan dari penelitian ini adalah menerapkan algoritma untuk mengidentifikasi tomat yang mengandung pestisida dengan menggunakan Learning Vector Quantization (LVQ). Diharapkan penelitian ini dapat dimanfaatkan untuk dapat membantu untuk mengenali tomat yang mengandung pestisida. Sehingga meminimalisir resiko dalam memilih tomat yang mengandung pestisida.

\section{TINJAUAN PUSTAKA}

Beberapa penelitian yang terkait antara lain seperti Penelitian dengan judul "Sistem Klasifikasi Jenis Beras Menggunakan Metode Learning Vector Quantization", sistem yang dibuat pada penelitian ini adalah sistem yang dapat melakukan klasifikasi jenis beras menggunakan metode Learning Vector Quantization. Dimana sistem dapat berjalan juga memanfaatkan pengolahan citra digital, karena data yang digunakan adalah kumpulan foto jenis beras. Jenis beras yang digunakan untuk penelitian ini adalah beras putih dan kelas beras ketan. Karena sekilas terlihat mirip bentuk dan warna keduanya.
Metode pengolahan citra yang digunakan untuk membantu kinerja sistem adalah metode grayscale, dengan menggunakan grayscale dapat menyatukan nilai piksel red, green, blue (RGB) menjadi sebuah nilai piksel yang memiliki derajat keabuan. Untuk memperkecil nilai piksel dilakukan proses beras putihisasi data, dimana metode yang digunakan dalam penelitian ini adalah Min-Max Normalization. Data foto beras yang digunakan untuk melatih data sebanyak 80 data, terdiri dari 30 data yang terindikasi jenis beras putih, dan 30 data yang jenis kelas beras ketan. Sedangkan banyaknya data jenis beras yang digunakan untuk menguji yaitu sebanyak 20 data, terdiri dari 10 data yangtermasuk kelas jenis beras putih, dan 10 data yang termasuk jenis kelas beras ketan.Sistem klasifikasi jenis beras dengan menggunakan algoritma Learning Vector Quantization telah berhasil dibangun, dimana sistem dapat berjalan cukup baik dengan akurasi sebesar $53,33 \%$ ketika dilakukan pengenalan menggunakan data training, dan sebesar $50 \%$ menurut pengenalan data testing[1].

Penelitian dengan judul "Perangkat Lunak Deteksi Uang Palsu Berbasis LVQ Memanfaatkan Ultraviolet", penelitian ini bertujuan untuk mengaplikasikan pemrosesan citra digital dan jaringan syaraf metode LVQ guna menghasilkan sebuah perangkat lunak deteksi uang palsu. Citra masukan berupa citra penari yang muncul dari uang kertas limapuluh ribuan rupiah akibat pendaran cahaya lampu ultraviolet. Metode penelitian meliputi studi literatur yang berkompeten, metode pengumpulan data citra uang palsu dari bank-bank konvensional, dan implementasi pengkodean menggunakan bahasa pemrograman Visual. Citra ciri bergambar penari berukuran 90x114 piksel diekstraks nilai RGB-nya. Nilai RGB ini menjadi variabel masukan bagi LVQ. Algoritma Linear Vector Quantization (LVQ) terbukti sangat baik diterapkan dalam sistem deteksi uang palsu dengan setingan terbaik adalah Learning Rate $=0,02$ dan MaxEpoh $=1000$. Hasil yang diperoleh dari penelitian berupa perangkat lunak deteksi uang palsu berbasis LVQ, dengan keberhasilan pendeteksian hingga $100 \%$ baik pada 20 buah data citra uji iluminasi maupun 14 buah simulasi data citra uji kecerahan. Data citra uji iluminasi terdiri dari 10 citra uang palsu dan 10 citra uang asli. Data citra uji kecerahan terdiri dari 3 citra uang asli dan 11 citra uang palsu[2].

Penelitian dengan judul "Implementasi Metode Segmentasi dan LVQ untuk Identifikasi Citra Daging Sapi dan Babi”, pada penelitian ini dibangun sistem pengolahan citra untuk mengidentifikasi daging sapi dan babi.Terdapat dua tahapan dalam proses identifikasi yaitu tahap pelatihan (training) dan pengujian (testing). Pengambilan data latih dan uji (citra daging) menggunakan kamera. Proses identifikasi dimulai dengan melakukan segmentasi citra menggunakan metode Spatial Fuzzy C-Means 
untuk memisahkan obyek (daging) dan background. Setelah diperoleh objek kemudian dilakukan proses ekstraksi ciri warna menggunakan metode HSV dan ciri tekstur dengan GLCM. Berdasarkan nilai hasil ekstrasi ciri warna (HSV) dan tekstur (GLCM), dilakukan proses klasifikasi menggunakan Learning Vector Quatization (LVQ). Data yang digunakan sebanyak 65 dengan dua variasi yaitu pertama jumlah data latih 50 dan data uji 15 serta jumlah data latih 30 dan data uji 15. Pengujian dilakukan dengan berbagai learning rate $(\alpha)$ yaitu $0.03,0.05,0.075$ dan 0.1. Hasil pengujian memperlihatkan sistem yang dibangun dapat mengenali citra daging sapi dan citra daging babi dengan persentase nilai akurasi tertinggi $80 \%$ dengan nilai learning rate $(\alpha) 0.1$ dan jumlah data latih 30 , nilai minimal learning rate (Mina) yang digunakan adalah 0,01 dan nilai pengurangan $\alpha$ adalah 0,1 [3].

Penelitian dengan judul "Identifikasi Kematangan Buah Mentimun Berbasis Citra Digital Menggunakan Jaringan Syaraf Tiruan Backpropagation", mengidentifikasi tingkat kematangan buah dengan menggunakan GLCM sebagai ekstraksi fitur dan menggunakan jaringan syaraf tiruan Backpropagation untuk pengujian serta training sehingga penelitian tersebut menhasilkan akurasi 89,6\% [4].

Penelitian dengan judul "Identifikasi Jenis Dan Mutu Teh Menggunakan Pengolahan Citra Digital dengan Metode Jaringan Syaraf Tiruan”, Penelitian ini menerapkan metode pengolahan citra digital dengan teknik Learning Vector Quantization yang menggunakan 6 parameter warna yaitu R, G, B, H, $\mathrm{S}$, dan I sebagai neuron input dan 13 mutu dari 3 jenis teh sebagai neuron output. Penelitian menggunakan 403 citra dengan perbandingan training dan testing sebesar 80:20. Akurasi training diperoleh sebesar 62,7\%. Prediksi menggunakan 26 sampel citra teh berbeda menunjukkan tingkat akurasi sebesar $42,31 \%$ [5].

\section{METODE PENELITIAN}

Jalannya sistem dalam proses penelitian ditunjukkan pada Gambar 1.

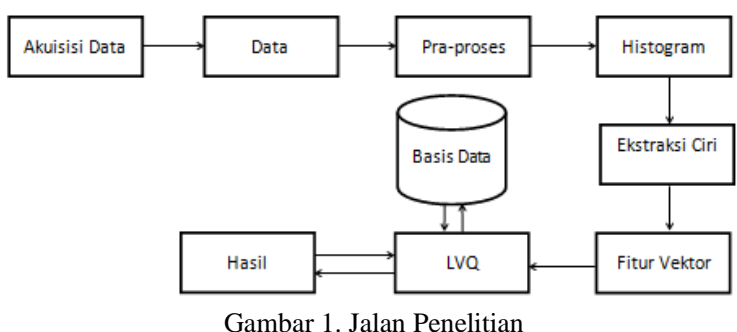

\subsection{Akuisisi Data}

Alat yang digunakan untuk pengambilan gambar adalah kamera smartphone Samsung A30 dengan kamera 16 mega piksel. Pengambilan dilakukan dengan jarak $7 \mathrm{~cm}$ vertikal di atas. Data citra tomat yang diambil diupayakan memiliki pencahayaan yang normal dan jarak pengambilan yang sama.

\subsection{Data}

Tahap akuisisi data yang dilakukan akan menghasilkan sebuah data yang berupa citra tomat yang mengandung pestisida. Citra tomat ini yang digunakan pada pemrosesan tahap berikutnya.

\subsection{Pra-proses}

Tahapan pra proses ini meliputi cropping dan grayscale. Cropping merupakan teknik pemotongan gambar yang digunakan untuk menentukan secara tepat bagian yang ingin diolah. Cropping bertujuan untuk mempermudah menganalisis citra dan memperkecil ukuran penyimpanan citra. Pada proses cropping dilakukan dengan memotong ukuran citra menjadi 100x100 piksel, sehingga akan mempercepat proses komputasi pada tahap selanjutnya. Setelah tahap cropping selesai dilakukan, proses selanjutnya adalah dengan mengubah citra dari tiga layer menjadi satu layer gray. Proses dari grayscale ditunjukkan pada Gambar 2.

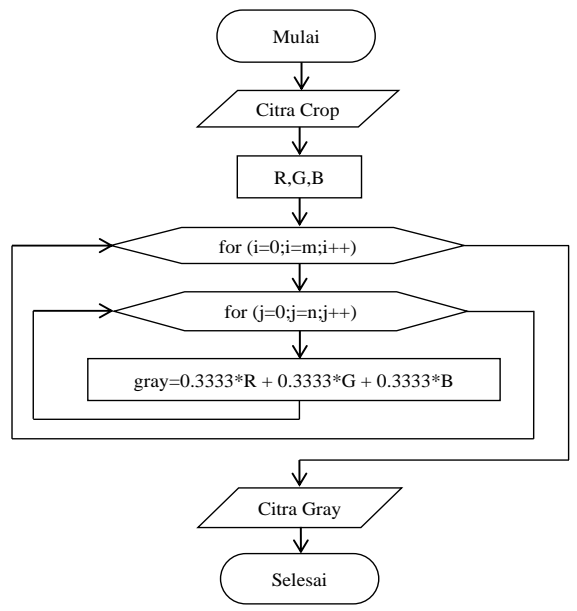

Gambar 2. Diagram Alir Proses Grayscale [6]-[8]

Keterangan :

Citra Crop : citra yang didapat dari proses crop

Layer RGB : layer merah, hijau dan biru dari citra crop

$\mathrm{m}$ : banyaknya piksel baris dari citra crop

$\mathrm{n}$ : banyaknya piksel kolom dari citra crop

citra gray : citra yang dihasilkan dari proses gray

\subsection{Histogram}

Citra yang sudah menjadi grayscale diproses untuk menentukan komposisi warna RGB yang digambarkan ke dalam grafik derajat keabuan (gray level). Histogram warna merepresentasikan distribusi jumlah piksel untuk tiap intensitas warna 
dalam citra. Diagram alir dari histogram citra ditunjukkan pada Gambar 3[9],[10].

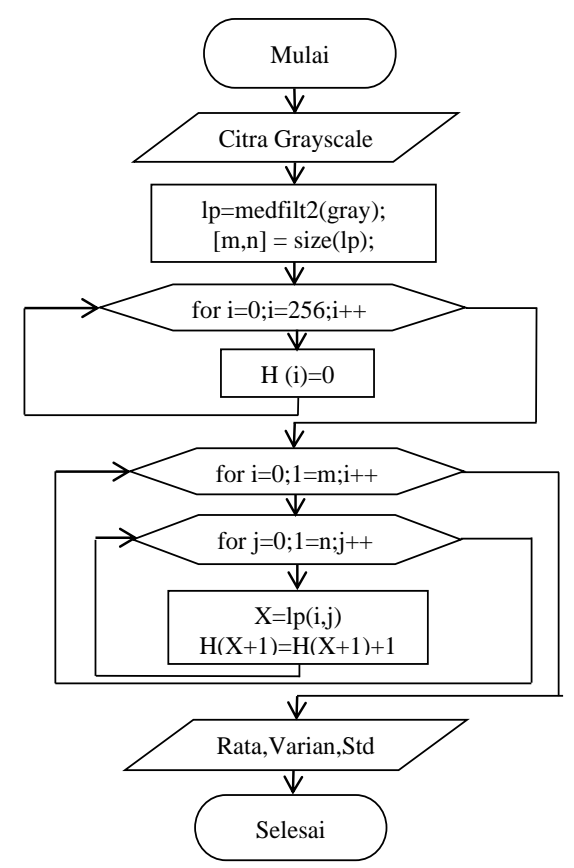

Gambar 3. Diagram Alir Histogram Citra

Keterangan :

Citra grayscale : citra yang didapat dari proses grayscale.

$\mathrm{m}$ : banyaknya piksel baris pada citra.

$\mathrm{n}$ : banyaknya piksel kolom pada citra

\subsection{Ekstraksi Ciri}

Ekstraksi ciri merupakan suatu pengambilan ciri (feature) dari suatu obyek, kemudian digunakan sebagai parameter untuk membedakan antara obyek satu dengan yang lainnya pada tahapan identidikasi citra. Proses ini berkaitan dengan kuantisasi karakteristik citra ke dalam sekelompok nilai ciri yang sesuai. Sehingga mendapatkan informasi kuantitatif dari ciri yang dapat membedakan kelaskelas suatu obyek. Dalam penelitian ini menggunakan 5 ciri yaitu rata-rata, varian, standar deviasi (std), kurtosis, dan skewness.

Rata-rata (mean) adalah suatu bilangan yang mewakili sekumpulan data. Nilai rata-rata dapat ditentukan dengan membagi jumlah data dengan banyaknya data. Rumus untuk mencari rata-rata dapat ditunjukkan oleh persamaan (1) :

$$
\mu=\frac{\sum_{i=1}^{N} X 1}{N}
$$

Keterangan :

$\mu=$ rata-rata

$\mathrm{N}=$ banyaknya data

$\mathrm{X}=$ jumlah data

Varian adalah ukuran seberapa tersebarnya data. Varian yang rendah menandakan data yang berkelompok dekat satu sama lain. Varian yang tinggi menandakan data yang lebih tersebar. Rumus untuk mencari varian dapat ditunjukkan oleh persamaan (2) :

$S^{2}=\frac{\sum_{i=1}^{n}(X i-\bar{X})^{2}}{n-1}$

Keterangan :

$S^{2}$ : varian

$\mathrm{Xi}$ : nilai $\mathrm{x}$ ke-i

$\bar{X}$ : rata-rata (mean)

$\mathrm{n}$ : jumlah data

Standar deviasi adalah nilai statistik yang digunakan untuk menentukan bagaimana sebaran data dalam sampel, dan seberapa dekat titik data ke mean atau rata-rata dari nilai sampel. Rumus mencari varian dapat ditunjukkan persamaan (3) :

$$
\sigma=\sqrt{\frac{\sum_{i=1}^{n}(X 1-\bar{X})^{2}}{n-1}}
$$

\section{Keterangan :}

$\sigma$ : standar deviasi

$\mathrm{Xi}$ : nilai $\mathrm{X}$ ke-1

$\bar{X}$ : rata-rata (mean)

$\mathrm{N}$ : jumlah data

Kurtosis adalah derajat ketinggian puncak atau keruncingan suatu distribusi. Nilainya biasanya merupakan nilai relatif terhadap distribusi normal. Salah satu ukuran yang digunakan untuk menyatakan derajat keruncingan kurva distribusi (kurtosis) ini menggunakan momen keempat di sekitar nilai mean dan dirumuskan sesuai persamaan (4):

Koefisien momen kurtosis:

$$
a_{4}=\frac{m_{4}}{(\sigma)^{4}}=\frac{m_{4}}{m_{2}^{2}} \text {. }
$$

Kurva distribusi normal yang tidak terlalu runcing dan tidak terlalu datar dinamakan mesokurtik (normal) dengan $\alpha_{4}=3$ (sekitar 3), sedangkan yang runcing disebut leptokurtik dengan $\alpha_{4}>3$, dan yang datar disebut platikurtik dengan $\alpha_{4}<$ 3. Kurtosis distribusi (Gamma dan Weibull) relatif terhadap distribusi normal, sehingga sebagai bentuk perbandingan dari distribusi normal sering didefinisikan sesuai persamaan (5):

$$
a_{4}=\frac{m_{4}}{(\sigma)^{4}}-3
$$

Kemiringan (Skewness) merupakan derajat ketidaksimetrian (keasimetrisan) atau dapat pula didefinisikan sebagai penyimpangan dari kesimetrian suatu distribusi. Jika sutu kurva frekuensi yang (poligon frekuensi yang terhaluskan) dari maksimum tengah, maka distribusi seperti ini 
dikenal dengan nama distribusi miring ke kanan, atau memiliki kemiringan positif. Untuk kondisi kebalikannya, distribusinya dikenal dengan distribusi miring ke kiri, atau memiliki kemiringan negatif. Kemiringan dapat ditunjukkan oleh persamaan (6).

Kemiringan $=\frac{3(\text { mean }- \text { median })}{\text { standar deviasi }}=\frac{3(\overline{\mathrm{X}}-\text { median })}{\mathrm{s}}$

\subsection{Fitur Vektor}

Setelah melakukan ekstraksi ciri dari citra tomat maka akan diperoleh sebuah ciri dalam bentuk vektor. Ciri tersebut kemudian disimpan dalam database yang digunakan sebagai acuan untuk proses pelatihan. Dari proses pelatihan akan diperoleh bobot akhir. Pengenalan data uji dilakukan dengan membandingkan bobot akhir dengan ciri data uji, kemudian mencari jarak terdekat untuk menentukan kelasnya.

\subsection{Identifikasi Menggunakan Learning Vector Quantization (LVQ)}

Learning Vector Quantization adalah sebuah metode klasifikasi dimana setiap unit output mempresentasikan sebuah kelas. Learning Vector Quantization digunakan untuk pengelompokan, dimana jumlah kelompok sudah ditentukan target dan kelasnya. Kelas-kelas yang didapatkan dari sebagai hasil dari lapisan kompetitif ini tergantung pada jarak antara vektor-vektor input. Jika dua vektor input mendekati sama, maka lapisan kompetitif akan meletakkan kedua vektor input tersebut ke dalam kelas yang sama. Sehingga dapat melakukan proses identifikasi pestisida pada tomat.

Proses Learning Vektor Quantization dapat dilihat pada Gambar 4 [11]-[15].

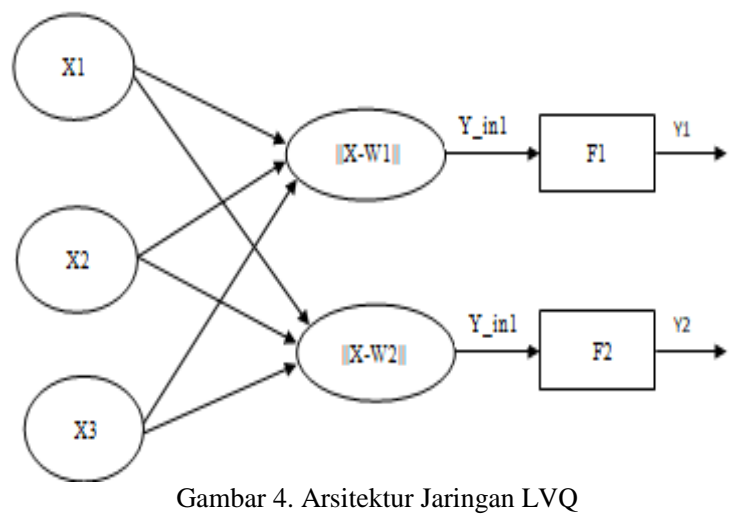

Keterangan :

$\mathrm{X} 1 \ldots \mathrm{n}=$ Vektor masukan .

$\mathrm{F}$ = Lapisan kompetitif.

Y_in = Masukan ke lapisan kompetitif.

$\mathrm{Y}=$ Keluaran.

$\mathrm{W}=$ Vektor bobot untuk unit keluaran.

$\| \mathrm{X}-\mathrm{W} 1 \ldots \mathrm{n}=$ Selisih nilai jarak Euklidean antara vektor input.

\section{HASIL DAN PEMBAHASAN}

\subsection{Akuisisi Data Citra}

Hasil pengambilan citra menggunakan smartphone ditunjukkan pada Gambar 5.

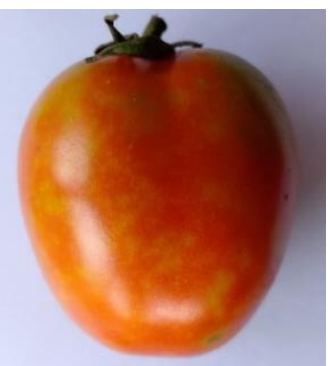

(a)

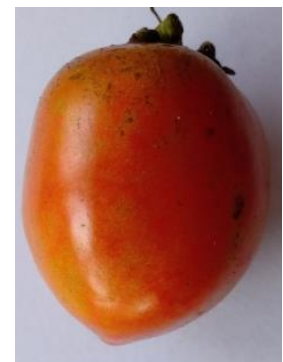

(b)
Gambar 5. Citra (a) Tomat Berpestisida dan Citra (b) Tomat Tidak Berpestisida

\subsection{Pra-proses}

Hasil proses cropping dapat ditunjukkan pada Gambar 6.

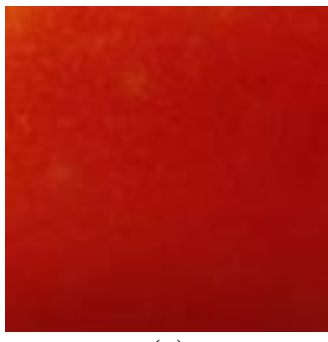

(a)

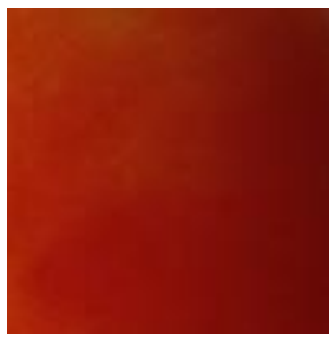

(b)
Gambar 6. Citra Hasil Cropping (a) Tomat Berpestisida dan Citra (b) Tomat Tidak Berpestisida

Proses selanjutnya mengubah data citra ke grayscale dengan membagi citra tiga layer RGB menjadi satu layer grayscale, yang ditunjukkan pada Gambar 7.

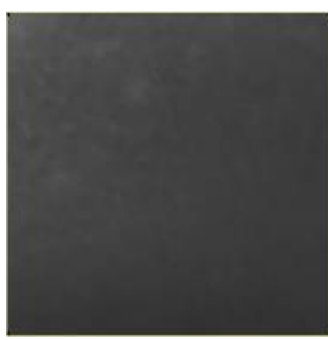

(a)

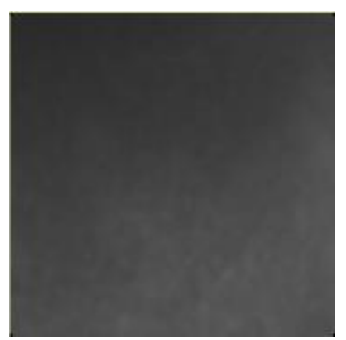

(b)
Gambar 7. Citra Hasil Grayscale (a) Tomat Berpestisida dan Citra (b) Tomat Tidak Berpestisida

\subsection{Histogram}

Proses selanjutnya yaitu mengolah data citra menjadi histogram. Setelah melalui tahap pra-proses data citra kemudian dicari derajat keabuannya. Citra masukan mempunyai 256 derajat keabuan yang nilainya 0-255. Derajat keabuan yang dimiliki citra tomat akan ditunjukkan dalam grafik. Data citra 
setelah dilakukan proses histogram ditunjukkan pada Gambar 8.

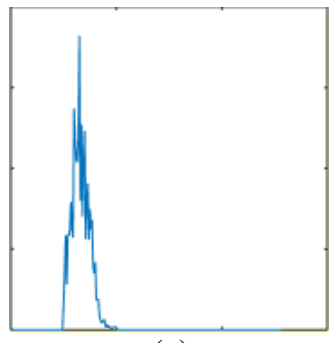

(a)

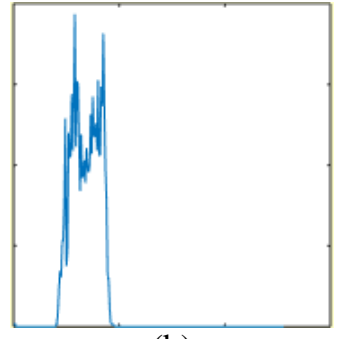

(b)
Gambar 8. Histogram Citra (a) Tomat Berpestisida dan Citra (b) Tomat Tidak Berpestisida

\subsection{Ekstraksi Ciri}

Data citra tomat yang telah diproses menggunakan histogram kemudian dilakukan ekstraksi ciri menggunakan rata-rata, varian, standar deviasi (std), kurtosis, dan skewness.

\subsection{Learning Vektor Quantization (LVQ)}

Proses pelatihan pada jaringan syaraf tiruan Learning Vector Quantization (LVQ) menggunakan parameter untuk mengetahui persentase keberhasilan tertinggi[16]. Pelatihan dilakukan untuk mencari bobot akhir yang digunakan dalam proses pengujian. Parameter Learning Vector Quantization (LVQ) dalam pelatihan ditunjukkan pada Tabel 1 .

Tabel 1. Parameter LVQ

\begin{tabular}{ll}
\multicolumn{2}{c}{ Tabel 1. Parameter LVQ } \\
\hline \multicolumn{1}{c}{ Parameter } & \multicolumn{1}{c}{ Nilai } \\
\hline Jumlah Data Pelatihan & 80 \\
Jumlah Data Uji & 80 \\
Jumlah Pola Target & 2 \\
Variasi Laju Pelatihan $(\alpha)$ & 0,$1 ; 0,01 ; 0,001$ \\
Update Laju Pelatihan & $\alpha=\alpha-\alpha(\mathrm{dec} \alpha)$ \\
Variasi Penurunan Laju Pelatihan $(\operatorname{dec} \alpha)$ & 0,$1 ; 0,2 ; 0,3 ; 0,4 ;$ \\
& 0,$5 ; 0,6 ; 0,7 ; 0,8 ;$ \\
Minimum Laju Pelatihan yang Diharapkan & 0,9 \\
Maksimum Iterasi & 0,000001 \\
Jumlah Data Pelatihan & 1000 \\
\hline
\end{tabular}

Pada penelitian ini seluruh data citra sebanyak 80 data. Untuk data yang digunakan sebagai bobot awal adalah data yang mewakili kelas (target), data tersebut diambil secara acak pada masing-masing kelas pada data yang ada. Bobot awal yang digunakan dalam penelitian ini dapat dilihat pada Tabel 2.

Tabel 2. Bobot Awal

\begin{tabular}{|c|c|c|c|c|c|}
\hline 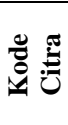 & & 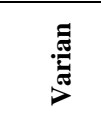 & 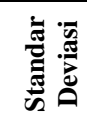 & 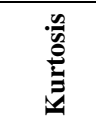 & 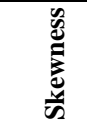 \\
\hline O01 & 48.188 & 232.225 & 15.239 & 7.852 & 2.4389 \\
\hline P01 & 45.324 & 379.763 & 19.488 & 17.077 & 3.6418 \\
\hline
\end{tabular}

Tabel 2 menunjukkan bobot yang pertama untuk kelas 1 yaitu tomat yang tidak mengandung pestisida dan kelas 2 yaitu tomat yang mengandung pestisida.

Database digunakan sebagai data pelatihan dengan menentukan target dan bobot awal. Target dibagi menjadi 2 kelas, yaitu kelas 1 untuk tomat yang tidak mengandung pestisida, dan kelas 2 untuk tomat yang mengandung pestisida, dengan masingmasing kelas ada 40 data dengan total 80 data pelatihan. Bobot awal diambil pada salah satu data masing-masing kelas dari data hasil ekstraksi ciri yang sudah dibuat. Dalam menentukan hasil kinerja identifikasi citra tomat dilakukan dengan mengubah parameter laju pelatihan awal (alfa) dan penurunan laju pelatihan (decalfa).

Kinerja dari data pelatihan (learning) identifikasi tomat yang mengandung pestisida dan tidak mengandung pestisida menggunakan metode Learning Vector Quantization (LVQ) dapat dilihat pada Tabel 3.

Tabel 3. Unjuk Kerja Identifikasi Tomat Berpestisida dan Tidak Berpestisida Data Pelatihan

\begin{tabular}{ccccc}
\hline No & Dec Alfa & Alfa & Iterasi & Komulatif $(\%)$ \\
\hline 1 & 0.1 & 0.1 & 110 & 50.00 \\
2 & 0.1 & 0.01 & 88 & 50.00 \\
3 & 0.1 & 0.001 & 66 & 5.00 \\
4 & 0.2 & 0.1 & 52 & 50.00 \\
5 & 0.2 & 0.01 & 42 & 43.33 \\
6 & 0.2 & 0.001 & 31 & 97.50 \\
7 & 0.3 & 0.1 & 33 & 50.00 \\
8 & 0.3 & 0.01 & 26 & 41.25 \\
9 & 0.3 & 0.001 & 20 & 97.50 \\
10 & 0.4 & 0.1 & 23 & 50.00 \\
11 & 0.4 & 0.01 & 19 & 18.75 \\
12 & 0.4 & 0.001 & 14 & 97.50 \\
13 & 0.5 & 0.1 & 17 & 50.00 \\
14 & 0.5 & 0.01 & 14 & 12.50 \\
15 & 0.5 & 0.001 & 10 & 97.50 \\
16 & 0.6 & 0.1 & 13 & 50.00 \\
17 & 0.6 & 0.01 & 11 & 6.25 \\
18 & 0.6 & 0.001 & 8 & 97.50 \\
19 & 0.7 & 0.1 & 10 & 50.00 \\
20 & 0.7 & 0.01 & 8 & 3.75 \\
21 & 0.7 & 0.001 & 6 & 97.50 \\
22 & 0.8 & 0.1 & 8 & 50.00 \\
23 & 0.8 & 0.01 & 6 & 3.75 \\
24 & 0.8 & 0.001 & 5 & 98.75 \\
25 & 0.9 & 0.1 & 5 & 50.00 \\
26 & 0.9 & 0.01 & 4 & 98.75 \\
27 & 0.9 & 0.001 & 3 & \\
\hline & & & & \\
\hline
\end{tabular}

Tabel 3 menunjukkan hasil unjuk kerja citra pelatihan terdapat persentase tertinggi yaitu $98.75 \%$. Dari alfa dan decalfa tersebut kemudian menghasilkan bobot akhir yang digunakan untuk pengujian. Pengujian dilakukan dengan mencari jarak terdekat antara bobot akhir dengan data uji untuk menentukan kelasnya.

\begin{tabular}{|c|c|c|c|c|c|}
\hline ن & 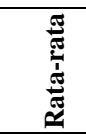 & 离 & 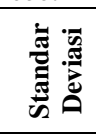 & 参 & 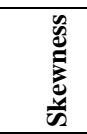 \\
\hline 1 & 61.829 & 241.531 & 15.844 & 9.752 & 2.5489 \\
\hline 2 & 51.709 & 388.800 & 19.546 & 31.496 & 4.6973 \\
\hline
\end{tabular}


Pengenalan data pelatihan yang paling baik akan disimpan menjadi bobot akhir dan akan digunakan untuk melakukan pengenalan terhadap data uji. Bobot akhir ditunjukkan pada Tabel 4.

Pengenalan dilakukan dengan mencari jarak terdekat antara bobot akhir dengan data uji. Dari data tersebut kemudian dapat diketahui data uji. Pengenalan data uji tomat berpestisida dan tidak berpestisida dapat dilihat pada Tabel 5 .

Tabel 5. Unjuk Kerja Identifikasi Tomat Berpestisida dan Tidak

\begin{tabular}{ccccc}
\multicolumn{5}{c}{ Berpestisida Data Pelatihan } \\
\hline No & Dec Alfa & Alfa & Iterasi & Komulatif $(\%)$ \\
\hline 1 & 0.1 & 0.1 & 110 & 50.00 \\
2 & 0.1 & 0.01 & 88 & 50.00 \\
3 & 0.1 & 0.001 & 66 & 6.25 \\
4 & 0.2 & 0.1 & 52 & 50.00 \\
5 & 0.2 & 0.01 & 42 & 50.00 \\
6 & 0.2 & 0.001 & 31 & 96.25 \\
7 & 0.3 & 0.1 & 33 & 50.00 \\
8 & 0.3 & 0.01 & 26 & 42.50 \\
9 & 0.3 & 0.001 & 20 & 96.25 \\
10 & 0.4 & 0.1 & 23 & 50.00 \\
11 & 0.4 & 0.01 & 19 & 27.50 \\
12 & 0.4 & 0.001 & 14 & 96.25 \\
13 & 0.5 & 0.1 & 17 & 50.00 \\
14 & 0.5 & 0.01 & 14 & 20.00 \\
15 & 0.5 & 0.001 & 10 & 97.50 \\
16 & 0.6 & 0.1 & 13 & 50.00 \\
17 & 0.6 & 0.01 & 11 & 16.25 \\
18 & 0.6 & 0.001 & 8 & 97.50 \\
19 & 0.7 & 0.1 & 10 & 50.00 \\
20 & 0.7 & 0.01 & 8 & 12.50 \\
21 & 0.7 & 0.001 & 6 & 97.50 \\
22 & 0.8 & 0.1 & 8 & 50.00 \\
23 & 0.8 & 0.01 & 6 & 10.00 \\
24 & 0.8 & 0.001 & 5 & 97.50 \\
25 & 0.9 & 0.1 & 5 & 50.00 \\
26 & 0.9 & 0.01 & 4 & 7.50 \\
27 & 0.9 & 0.001 & 3 & 97.50 \\
\hline & & & &
\end{tabular}

Berdasarkan Tabel 5 menunjukkan hasil pengujian terbaik dengan persentase tertinggi yaitu $97.5 \%$.

\section{KESIMPULAN}

Berdasarkan hasil penelitian maka dapat disimpulkan bahwa unjuk kerja terbaik pelatihan dengan 80 data diperoleh akurasi sebesar $98.75 \%$ dengan rincian tomat yang tidak mengandung pestisida $100 \%$ dan tomat yang mengandung pestisida $97.5 \%$ dengan alfa 0.001 dan decalfa 0.9 sedangkan unjuk kerja pengujian dengan 80 data diperoleh akurasi sebesar $97.5 \%$ dengan rincian tomat yang tidak mengandung pestisida $97.5 \%$ dan tomat yang mengandung pestisida $97.5 \%$ dengan alfa 0.001 dan decalfa 0.9 .

Saran pengembangan yang dapat dilakukan pada sistem ini untuk penelitian selanjutnya adalah proses akuisisi akan lebih maksimal apabila pencahayaan dan jarak lebih tepat. Sehingga citra yang dihasilkan dapat mencirikan tomat dengan maksimal. Selain itu, penambahan data penelitian diharapkan dapat menambah tingkat keakuratannya.

\section{DAFTAR PUSTAKA}

[1] P. Utomo, "Sistem Klasifikasi Jenis Beras Menggunakan Metode Learning Vector Quantization," Jurnal Ilmiah Ilmu - ilmu Teknik, vol. I, pp 61-67, 2016.

[2] D. Harjunowibowo, "Perangkat Lunak Deteksi Uang Palsu Berbasis LVQ Memanfaatkan Ultraviolet", Seminar Nasional Pendidikan Biologi FKIP UNS, 2010, pp. 342-352.

[3] Jasril, L. Handayani, E. Budianita, \& F. U. Amri, "Implementasi Metode Segmentasi dan LVQ untuk Identifikasi Citra Daging Sapi dan Babi," Seminar Nasional Teknologi Informasi, Komunikasi dan Industri (SNTIKI), 2017, pp. 283-292.

[4] I. Fathurrahman, A. M. Nur, \& Fathurrahman. "Identifikasi Kematangan Buah Mentimun Berbasis Citra Digital Menggunakan Jaringan Syaraf Tiruan Backpropagation," Infotek : Jurnal Informatika dan Teknologi, pp. 27-33, 2019.

[5] M. Effendi, Fitriyah, \& U. Effendi, "Identifikasi Jenis Dan Mutu Teh Menggunakan Pengolahan Citra Digital dengan Metode Jaringan Syaraf Tiruan," Jurnal Teknotan, vol. 11, no. 2, pp. 67-76, 2017.

[6] A. M. Arymurthy, Pengantar Pengolahan Citra. Jakarta: Elex Media Komputindo. 1991.

[7] R. Munir, Pengolahan Citra Digital Dengan Pendekatan Algoritmik. Bandung: Informatika, 2004.

[8] T. Sutoyo, Teori Pengolahan Citra Digital. Yogyakarta: Andi Publisher, 2009.

[9] E. Kartika, R. Yusuf, \& A. Syakur, "Pertumbuhan dan Hasil Tanaman Tomat (Lycopersicum esculentum Mill.) Pada Berbagai Persentase Naungan," $e-J$. Agrotekbis, pp. 717-724, 2015.

[10] U. Yuliana, R. N. Whidhiasih, \& Maimunah, "Identifikasi Rasa Buah Mangga Gedong Gincu Cirebon Berdasarkan Citra Red-GreenBlue Menggunakan Jaringan Syaraf Tiruan," Jurnal Penelitian Ilmu Komputer, System Embedded \& Logic, pp. 61-68, 2016.

[11] R. Hamidi, M. T. Furqon, \& B. Rahayudi, "Implementasi Learning Vector Quantization (LVQ) untuk Klasifikasi Kualitas Air Sungai," Jurnal Pengembangan Teknologi Informasi dan Ilmu Komputer, vol. I, pp. 1758-1763, 2017.

[12] R. R. Jordy, R. Magdalena, \& L. Novamizanti, "Klasifikasi Motif Batik Solo Menggunakan Histogram of Oriented Gradient Dan Learning Vector Quantization," e-Proceeding of Engineering, 2018, V, pp. 5079-5085. 
16 Jurnal Teknik Informatika (JUTIF), Vol. 2, No. 1, Juni 2021, hlm. 9-16

[13] D. Y. Qur'ani, \& S. Rosmalinda, “Jaringan syaraf tiruan learning vector quantization untuk aplikasi pengenalan tanda tangan," Seminar Nasional Aplikasi Teknologi Informasi, 2010, pp. 6-10.

[14] A. S. Romadhon, \& V. T. Widyaningrum, "Klasifikasi Mutu Jeruk Nipis dengan Metode Learning Vector Quantization (LVQ)," Jurnal Ilmiah Rekayasa, pp. 121128, 2015.

[15] U. Sudibyo, D. P. Kusumaningrum, E. H. Rachmawanto, \& C. A. Sari, "Optimasi Algoritma Learning Vector Quantization (LVQ) Dalam Pengklasifikasian Citra Daging Sapi dan Daging Babi Berbasis GLCM dan HSV," Jurnal SIMETRIS, vol. IX, pp. 1-10, 2018.

[16] N. D. Miranda, L. Novamizanti, \& S. Rizal, "Convolutional Neural Network Pada Klasifikasi Sidik Jari Menggunakan Resnet50", Jurnal Teknik Informatika (Jutif), vol. 1, no. $2,2020$. 